\title{
COCHLEARIA POLONICA FRÖHL. (BRASSICACEAE), A NARROW ENDEMIC SPECIES OF SOUTHERN POLAND: HISTORY OF CONSERVATION EFFORTS, OVERVIEW OF CURRENT POPULATION RESOURCES AND GENETIC STRUCTURE OF POPULATIONS
}

\author{
ElŻBIETA CIEŚLAK ${ }^{1}$, RÓŻA KAŹMIERCZAKOWA ${ }^{2}$, MiCHAŁ RONIKIER ${ }^{1}$ \\ ${ }^{1} \mathrm{~W}$. Szafer Institute of Botany, Polish Academy of Sciences \\ Lubicz 46, 31-512 Kraków Poland \\ e-mail: e.cieslak@botany.pl \\ ${ }^{2}$ Institute of Nature Conservation, Polish Academy of Sciences \\ Mickiewicza 33, 31-120 Kraków Poland
}

(Received: December 10, 2009. Accepted: April 4, 2010)

\begin{abstract}
Cochlearia polonica Fröhl. (Brassicaceae) is one of the rarest species in the Polish and European flora and a taxon endemic to a very small area in southern Poland. Due to industrial activities and subsequent transformation of habitats it was extinct in all natural localities around 1994. The persistence of the species was ensured thanks to the active protection efforts including a series of transplantations based on the material from the last and decreasing natural population. The history of conservation efforts of $C$. polonica provides a model example of successful active protection in the European flora. Here, we provide a complete review comprising the following aims: (i) outline of the discovery and taxonomic conceptions on $C$. polonica, (ii) review of conservation efforts aimed at preserving its populations, (iii) description of the existing population resources, and (iv) analysis of the genetic structure of all existing populations based on previously published data and new, supplementary results.
\end{abstract}

KEY WORDS: Cochlearia polonica, endemic species, transplantation, introduced population, conservation, genetic variation, genetic structure, AFLP.

\section{INTRODUCTION}

Human industrial activity frequently leads to transformations of natural habitats. Its influence can be both direct by land development and exploitation of entire sites, sometimes comprising unique habitats and rare species, and indirect by changing habitat conditions in the impact zone (e.g. land draining, microclimate change) or habitat fragmentation. This may cause the extinction of species, primarily stenotopic organisms able to exist in very narrow ecological niches only. Therefore, such species should be conserved, if still possible, by protecting preserved habitat fragments and/or by introducing individuals in new habitats, that is by establishing secondary localities.

The history of conservation efforts and transplantation of Cochlearia polonica Fröhl. (Brassicaceae), one of the rarest species in the Polish and European flora and a taxon endemic to a very small area in southern Poland, provides a model example of successful active protection in Poland.
A population of the species was planted in the spring area of the Centuria river (Southern Poland). Individuals were transferred from their natural locality in the vicinity of Olkusz which fully declined due to mining-related draining (Kwiatkowska 2001). Conservation efforts prevented a complete extinction of the species and thus both quantitative and qualitative impoverishment of the Polish flora.

Although Cochlearia polonica is one of unique elements of the Polish flora, relatively few data are available on the species in the literature. It has been included in the Red Data Book of Plants (Kwiatkowska 1993, 2001), but contributions providing systematic information on the taxon and indicating an urgent need to ensure its occurrence in nature have been published only recently (Kaźmierczakowa 2004; Baryła 2005). It is even more important to review conservation efforts and data on the population condition as the history of its protection by transplanting and founding a secondary population is an interesting example of protection measures in the scale of Europe. 
The aim of this study is to provide a complete overview of published and unpublished data on $C$. polonica in the Polish flora, and in particular: (i) to outline the history of its discovery and taxonomic conceptions, (ii) to present conservation efforts aimed at preserving its populations, (iii) to describe the current condition of the population, and (iv) to summarise and supplement the knowledge on the genetic structure of all existing populations with unpublished data.

\section{HISTORY OF THE DISCOVERY \\ OF THE SPECIES AND THE SYSTEMATIC RANK OF THE TAXON}

The occurrence of a plant belonging to the genus Cochlearia L. near Olkusz in the Wyżyna Śląsko-Krakowska upland was first reported by Zalewski (1886). Plants occurred in Olkusz Stary „over a ditch” (probably in the Sztolnia Ponikowska adit, as suggested by Kwiatkowska 1962). Zalewski defined the population as taxonomically belonging to Cochlearia officinalis L. It was reported under this name in the first edition of the Polish field flora (Szafer et al. 1924). The occurrence of the plant near Olkusz was confirmed by Piech (1924), who observed it in the Biała river (a tributary of the Biała Przemsza river) springfens and at a pond called Biała Karczma (Fig. 1). The plant was classified by Piech (1924) as a subspecies: C. officinalis L. subsp. pyrenaica (DC.) Rouy et Fouc. The morphological divergence of the plants belonging to these populations was first noted by Fröhlich $(1936,1937)$, who described them as a new species under the new name Cochlearia polonica E. Fröhlich (Fig. 2), placing the Latin diagnosis in a scheda for the exsiccate series: Rośliny Polskie. Plantae Poloniae Exsiccatae (1936). Chater and Heywood (1964) cited this publication when describing the genus Cochlearia L. in Flora Europaea and retained the species rank of $C$. polonica. However, the systematic position of the taxon was not specified in the second edition of Flora Europaea and it was included in the $C$. officinalis L. group there (Chater et al. 1993).

The differentiation of the taxon $C$. polonica by Fröhlich was based on morphological characters. Its distinctiveness from other species of the genus Cochlearia was further confirmed by cytological examinations: the taxon was demonstrated to be an autohexaploid with the chromosome number $2 \mathrm{n}=36$ and a basic number of chromosomes $\mathrm{x}=6$ (Bajer 1950). Besides C. polonica, the group of section $C o$ chlearia members also characterized by the basic number of chromosomes $\mathrm{x}=6$ includes the diploids $C$. pyrenaica

Fig. 1. Distribution map of existing transplanted populations of Cochlearia polonica and extinct natural and transplanted populations.

Abbrevation: A - approximate historical natural range of $C$. polonica; $\mathbf{B}$ extinct transplanted populations; $\mathbf{C}$ - existing transplanted populations. 1 - spring of Brda river; 2 - floodplain of Wilga river; 3 - The „Niebieskie Źródła" nature reserve; 4 - springs of Wiercica river; 5 - springfen of Rajecznica stream; 6 - springfens of Białka Zdowska river; 7 - springs of Rak stream; 8 - springfens of Centuria river; 9 - spring of Chechło stream; 10 - Biała river and its tributaries; 11 - springs in Kwaśniów village; 12 - springs of Biała Przemsza river near Golczowice; 13 - The „Siedem Źródeł” springfens in Pazurek village; 14 - tributary springs of Dłubnia river near Imbramowice; 15 - upper course of Sztoła river; 16 - spring in Psary village; 17 - tributary springs of Racławka river; 18 -The „Spod Graba" spring in Dolina Sąspowska valley; 19 - spring in Kostrze in borders of Kraków.
DC., C. macrorrhiza (Schur) Pobed., C. excelsa Zahlbr. ex Fritsch, and $C$. aestuaria (Lloyd) Heywood $(2 n=12)$, the tetraploid $C$. officinalis L. $(2 \mathrm{n}=24)$, and other higher polyploids: $C$. bavarica Vogt $(2 \mathrm{n}=36)$, and $C$. anglica $\mathrm{L}$. $(2 \mathrm{n}=48)$. The section contains also a second group, characterized by the basic chromosome number $\mathrm{x}=7$, represented by the following species: the diploid $C$. groenlandica $\mathrm{L}$. $(2 \mathrm{n}=14$, uni-

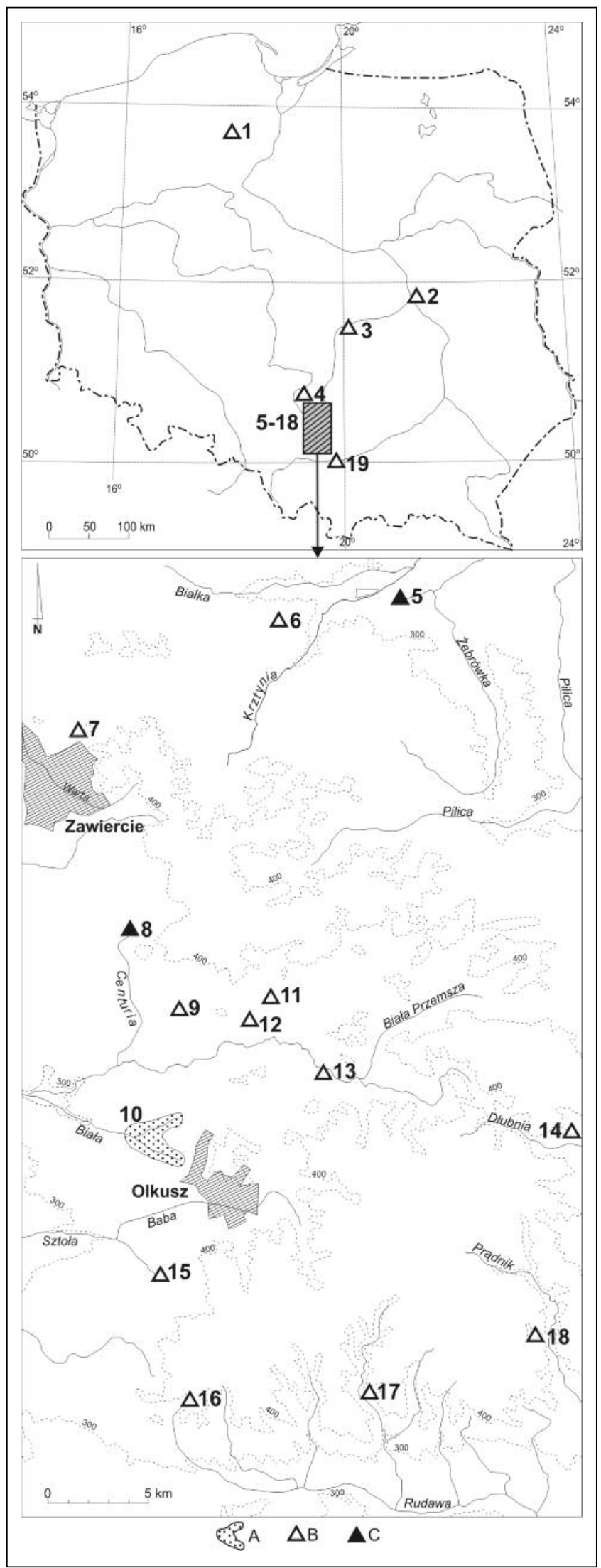




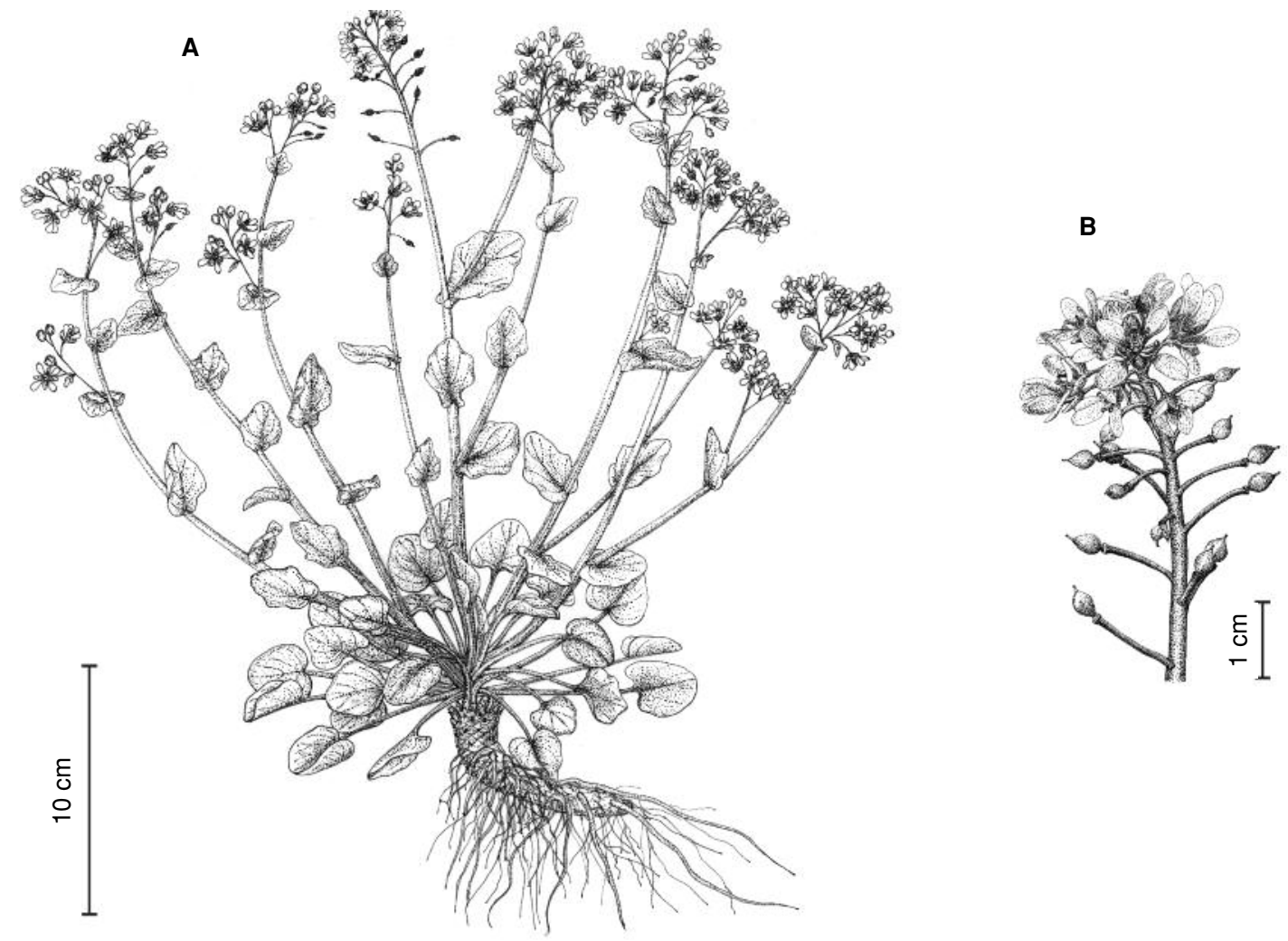

Fig. 2. Cochlearia polonica Fröhl: A - general habit; B - fragment of inflorescence. (drawn by J. Urbanik)

que 12) and the hexaploids: $C$. tatrae Borbás and $C$. danica L. $(2 \mathrm{n}=42)$ (Koch et al. 1998).

Recent molecular analyses show that $C$. polonica is clearly genetically different from populations of other Cochlearia species in Central Europe. In particular, the confusing taxonomic status of a Cochleria population in Ukraine, treated in some previous studies (including the Red Data Book in Ukraine - Sobko 1996), as C. polonica and in some as $C$. pyrenaica, was also verified based on examinations of genetic variation. It was shown that the population represented the diploid $C$. pyrenaica and not $C$. polonica, which confirmed the status of $C$. polonica as a taxon endemic to Southern Poland only (Cieślak and Ronikier 2006; Cieślak et al. 2007b; Kochjarová et al. 2006).

\section{HISTORY OF CONSERVATION EFFORTS AND THE CURRENT CONDITION OF POPULATION RESOURCES}

The occurrence of $C$. polonica in the springfen of the Biała river, a tributary of the Biała Przemsza river, in an area of ca. $4 \mathrm{~km}^{2}$ was observed by Alina Kwiatkowska (Institute of Nature Protection, Polish Academy of Sciences, Krakow) during inventory studies in the period between 1948 and 1952 (Kwiatkowska 1957). Plants were recorded around a vaucluse spring and shallow mid-forest streams with sandy bottoms and, less frequently, on boggy, peaty banks. The population was very numerous; $C$. polonica was a dominant species in many patches. In turn, A. Kwiatkowska did not record the occurrence of the plant by the Biała Karczma pond previously reported in the literature. The range of occurrence of $C$. polonica decreased considerably in the following ten years. The operation of the smelting factory in Bukowno and the need to drain zinc and lead ore mines led to a gradual draining of the area and caused changes in the local habitat conditions, especially in boggy areas. The upper courses of the Biała river and of its tributaries disappeared between 1958 and 1960 (Kwiatkowska 1962). A vast cone of depression formed when the factory expanded and new mines were opened, and the river system gradually disappeared over a large area. $C$. poloni$c a$ persisted in drying riverbeds over a number of years, but the viability and abundance of the population decreased around 1994 (Kwiatkowska 2001). A clear deterioration of habitat conditions caused a shortening of the plant's life cycle; biennial individuals must have dominated in the population at the time. Therefore, although Fröhlich (1936) in his diagnosis of the species described it as a usually perennial plant (planta plerumque perennis), C. polonica was defined by Kwiatkowska (1962) as a biennial and it was classified as such in later studies (e.g. Kwiatkowska 2001; Kaźmierczakowa 2004). Symbols for „biennial to perennial” were used to describe it in the first edition of Rośliny Polskie (Szafer et al. 1924); however the plant appeared there as „C. officinalis" and thus the characteristics may have referred to the latter, widely understood, species. Similarly, the plant was identified as a biennial to perennial in volume 3 of the Flora Polska (Kulczyński 1927), where it was reported as $C$. pyrenaica (additionally, a question mark followed the symbol of a biennial plant). On the other hand, a biennial plant symbol only is used (incorrectly) in the second edition of Rośliny Polskie (here reported as C. polonica; Szafer et al. 1953), which may be a printing error. This erroneous symbol was later repeated in volume 4 of the Flora Polski (Sychowa 1985). Long-term demographic and morphological observations confirm nevertheless that in optimal habitat conditions it is in fact a perennial plant (R. Kaźmierczakowa, unpublished data). 
As progressive land draining led to a complete disappearance of the river system in the upper Biała river basin in the 1970s, only few individuals of $C$. polonica occurred at natural localities in places at least periodically damp, e.g. due to snow and rainfall accumulation (Kwiatkowska 2001). It was therefore decided to establish a secondary locality of the species (Kwiatkowska, pers. comm.). About 11 individuals (n.b., Cieślak et al. 2007a reported 14 individuals due to an earlier, inaccurate information) were transferred from the upper Biała river to the Centuria river springfen (also located in the Wyżyna Śląsko-Krakowska upland; Fig. 1). R. Kaźmierczakowa and B. Szczęsny participated in founding the new locality. The transplantation site was selected based on previous habitat observations by B. Pawłowski (Institute of Botany, Jagiellonian University, Kraków), whose accurate ecological observations greatly contributed to the transplantation's success (A. Kwiatkowska, pers. comm.). Seedlings cultured from seeds were added by A. Kwiatkowska to the new stand in successive years. The plant reproduced very quickly and developed a numerous population with a normal demographic structure over a period of a few years (Kwiatkowska 2001; Kaźmierczakowa 2004). The genetic structure of the population was analysed after ca. 30 years and a considerable genetic variation (although lower than in comparison with, for instance, natural populations of $C$. tatrae having a similar abundance), and the genetic structure correlated to some extent with the population's spatial structure were shown (Cieślak et al. 2007a; see also below).

Using the material obtained from the Centuria river, A. Kwiatkowska (1994) established further 16 localities (Fig. 1). Three localities were situated in northern and central Poland: springs of the Brda river in the Laska village in the Tuchola Forests, Wilga river floodplain in the Wilga village in the Równina Garwolińska upland and springfens in the „Niebieskie Źródła” reserve near Tomaszów Mazowiecki in the Dolina Białobrzeska valley. Most efforts to establish new secondary localities concentrated however in the Wyżyna Śląsko-Krakowska upland. These were: the "Siedem Źródeł" springs in the Pazurek village, springs in the Kwaśniów village, tributary springs of the Biała Przemsza river near Golczowice, a karst vaucluse spring in Kostrze within Krakow borders, springs of the Wiercica river in the „Parkowe” nature reserve near the Złoty Potok village (locality established in 1977), springs of the Chechło stream in the Chechło village, the Białka Zdowska springs near Korczyce, tributary springs of Racława river near Krakow. Further secondary localities were established by A. Kwiatkowska and R. Kaźmierczakowa starting from 1992. These were: karst springs in the Psary village near Karniowice, "Spod Graba" spring in the Dolina Sąspowska valley in the Ojców National Park, springs of the Rak stream in Blanowice, tributary springs of the Dłubnia river near Imbramowice, the Rajecznica stream springs near Koniecpol. Attempts to introduce the species at secondary localities mostly failed. The latest attempt to introduce the species in the upper course of the Sztoła river carried out in 2007 did not bring positive results either (R. Kaźmierczakowa, A. Nowak-Dańda, P. Dańda, unpubl. data).

The plant persisted at the majority of secondary localities for only two to a few years and disappeared. The reasons for the disappearance were identified in some cases, e.g. the spring was channelled as a water source for the village in Psary, the plants were eaten by swans nesting on the floodplain downstream of the spring in Blanowice. Plant's disappearance was sometimes caused by excessive shading by trees and abundant litter fall, e.g. in the "Spod Graba” spring. The locality in the Wiercica springs persisted for over 30 years; however, the number of plants was always low. The population consisted of between ten and fifty plants in the years of the best development. It continued to decrease in the final period and only two blossoming plants persisted in 2008. This was most probably caused by increasing shading by trees, abundant tree-leaf fall in autumn and damage caused by tourists who numerously visit the well-known „Parkowe” nature reserve, within which Wiercica springs are located. The locality finally disappeared in 2009 following flooding caused by a small dam built downstream. C. polonica currently persists only at two localities: at the site of the first transplantation in the Centuria springs and in the Rajecznica springs.

Only the locality in Centuria, where the population comprises tens of thousands of individuals and occupies an area of ca. 30 ares, may be likely to survive in the long term. Centuria springs are protected as a nature monument and a Natura 2000 site. They are located in the „Orle Gniazda" Landscape Park. However, the vegetation in the springfen continues to be damaged, e.g. by quads driven illegally in the area. A change in water relationships, and habitat draining in particular, may be the most serious threat to $C$. polonica. Construction plans for a new mine in the vicinity of Zawiercie pose the greatest danger.

Rajecznica springs lie within the „Kępina” reserve. Forty-five plants grew at the stand in spring 2008. Almost $50 \%$ of them were blossoming individuals; however, hardly any seedlings were present. The plants were damaged by wild boars penetrating the area. Further 30 individuals were transplanted from Centuria in autumn 2008 (R. Kaźmierczakowa, unpubl. data). The transplantation was successful and the population increased to ca. 140 plants in the following year, half of which were juvenile individuals.

\section{ANALYSIS OF GENETIC VARIATION AND STRUCTURE OF COCHLEARIA POLONICA}

The knowledge of genetic variation and its spatial structure is critical for planning effective protection of threatened species (e.g. Escudero et al. 2003). In order to assess genetic variation in the introduced population of Cochlearia polonica and derived populations, the genetic structure of the species and genetic relationships among central European taxa of the genus Cochlearia have been examined in recent years as part of a broader research project on the genus Cochlearia in Poland and neighbouring countries (Cieślak and Ronikier 2006; Cieślak et al. 2007a, b). The material from the first and the only stable introduced population in the Centuria river springfens was examined at the first stage of the project (Cieślak et al. 2007a). The integrity of $C$. polonica was demonstrated in an extended analysis comprising all regional groups of localities of $C$. polonica, $C$. borzaeana, C. excelsa, $C$. pyrenaica and $C$. tatrae. It was confirmed that the species is represented exclusively by populations from southern Poland and, consequently, it is an endemic species with a very narrow range (Cieślak and Ronikier 2006; Cieślak et al. 2007b; E. Cieślak and M. Ronikier, unpubl. data). 
An extended, supplementary analysis of genetic variation and its spatial distribution within- and among existing populations of $C$. polonica was carried out in order to examine, as far as possible, the effects of the known transplantation and restitution history of the species on its current genetic structure. In order to determine genetic relationships among all contemporary populations, previous analyses of the population in Centuria (cf. Cieślak et al. 2007a) were supplemented in the present study and material collected from three populations that constitute the entire range of the species: Centuria, Rajecznica and the - disappeared at a later date - locality in Wiercica, was examined. A sample of 23 individuals covering the entire population area (selected from a broader collection performed in 2003) based on previous analyses was examined in the case of the population from Centuria (Cieślak et al. 2007a). Samples from the other localities were collected in 2007 and comprised material from 27 blossoming individuals from the locality in Rajecznica and from the only two individuals persisting at that time at the locality in the Wiercica valley springs. The samples (a total of 52 individuals) were analysed using AFLPs to determine polymorphism and the genetic variation of the species (for details on methods of the genetic and statistical analyses, see Cieślak et al. 2007a, b).

A total of 134 fragments (markers), including 67 (50\%) polymorphic markers, were recorded in the polymorphism analysis. Comparable numbers of polymorphic bands were recorded in the intraspecific analysis for populations in Centuria and Rajecznica: 55 (41\%) and 50 (37\%), respectively. Only eight polymorphic bands $(6 \%)$ were recorded in the extremely small and disappearing (two individuals) population in Wiercica (Table 1). The highest values of the parameters characterising the genetic variation of introduced populations of Cochlearia polonica in Centuria and Rajecznica (number of polymorphic markers, Nei and Shannon indices) are recorded for the population in Centuria, which is the oldest and the most numerous population (Table 1). Nevertheless, these differences are not statistically significant $(\mathrm{p}>0.01)$, which indicates a similarity in terms of genetic variation. The population in Wiercica was not included in these analyses due to the small size of the sample.

Among existing transplanted populations, only the population in Centuria can be described as stable and having a well developed demographical structure. A direct comparison of variation parameters with natural populations of $C$. polonica being not possible, the most appropriate natural case is provided by populations of $C$. tatrae, a closely related, polyploid, narrow endemic species. The genetic variation in the Centuria population of $C$. polonica was approximately twice as low as that in the demographically comparable natural populations of C. tatrae, however, ca. $30 \%$ of

TABLE 1. Statistic estimates of genetic diversity for three studied populations of Cochlearia polonica based on the AFLP analysis. $\mathrm{N}$ - number of studied individuals; $\mathrm{P} /(\%)$ - number and percentage of polymorphic bands; h - Nei's gene diversity; S - Shannon's index; * not computed due to small population sampling size.

\begin{tabular}{lcccc}
\hline Population & $\mathrm{N}$ & $\mathrm{P} /(\%)$ & $\mathrm{h}$ & $\mathrm{S}$ \\
\hline Centuria (C) & 23 & $55 /(41)$ & $0.15(0.2)$ & $0.22(0.29)$ \\
Rajecznica (R) & 27 & $50 /(37)$ & $0.13(0.2)$ & $0.19(0.27)$ \\
Wiercica (W) & 2 & $8 /(6)$ & $*$ & $*$ \\
\hline
\end{tabular}

polymorphic markers characterised this population $(\mathrm{Cie}-$ ślak et al. 2007a). We suppose that a very dynamic development of this population as early as in the first years after the transplantation may have been of considerable importance for partial neutralisation of the bottleneck effect associated with transplantation of a small number of individuals. Such a scenario is confirmed by the investigation of the biology of this species. Preliminary results showed that both production of seeds and germination of $C$. polonica are very high. One perennial, well developed plant produced on average about 3500 seeds (6800 maximally) and the seed germination in laboratory conditions reached between 75 and 90\% (A. Nowak-Dańda, P. Dańda, R. Kaźmierczakowa, unpublished data).

Cieślak et al. (2007a) demonstrated in the AFLP analysis the existence of a small but statistically significant correlation between individuals' genetic similarity and their spatial distribution in the population in Centuria.

On the other hand, a very low value of the Nei's genetic distance between the populations in Centuria and Rajecznica (0.04) indicates a lack of clear differentiation among the populations. The origin of the genetic material from the same source and a repeated input of derived populations with plants transplanted from Centuria undoubtedly influenced this pattern of genetic variation. Results of the analysis of pairwise relationships among individuals (Fig. 2) (UPGMA dendrogram based on the simple matching coefficient; PCO - data not shown) indicate the absence of a clear-cut division into genetic groups. Six individuals in Rajecznica are grouped together with individuals from Centuria while two individuals in Wiercica are in the same group as individuals from Rajecznica. The remainder of individuals from Rajecznica forms a separate cluster; however, it is characterised by very low bootstrap values. The bootstrap support for any of the main divisions did not exceed 30 (Fig. 3). The general profile indicates a high genetic similarity among the three populations. This was confirmed by AMOVA analysis results in which a share of within-population variation $(73.45 \%)$ considerably higher than amongpopulations variation $(26.55 \%$; $\mathrm{p}>0.01)$ was recorded. On the other hand, it should be stressed that the presence of a certain genetic structure and $\mathrm{F}_{\mathrm{ST}}$ equalling 0.26 may be somewhat surprising in the case of populations transplanted within only 30 years from the original material of 11 individuals. The values are influenced by factors related to populational demography, including processes such as the founder effect and genetic drift. Differentiation of the majority of the population in Rajecznica into a group separate from that in Centuria, despite the origin from the latter, may indicate the influence of such processes on a considerable change of the frequency of markers in the derived population. This is also confirmed by the fact that single population-characteristic AFLP bands were recorded in the populations in Rajecznica and Centuria. Individuals grouping within the Centuria cluster are very likely to represent episodes of later (recent) additional planting of the material from Centuria in the population in Rajecznica. Unfortunately, analyses of population genetics face a basic obstacle here, that is the lack of a detailed transplantation register where individual steps would be recorded, comprising e.g. the specific area of the origin of the material and of the enrichment of original plantations with further individuals from Centuria. Thus, it should be noted that in the present 


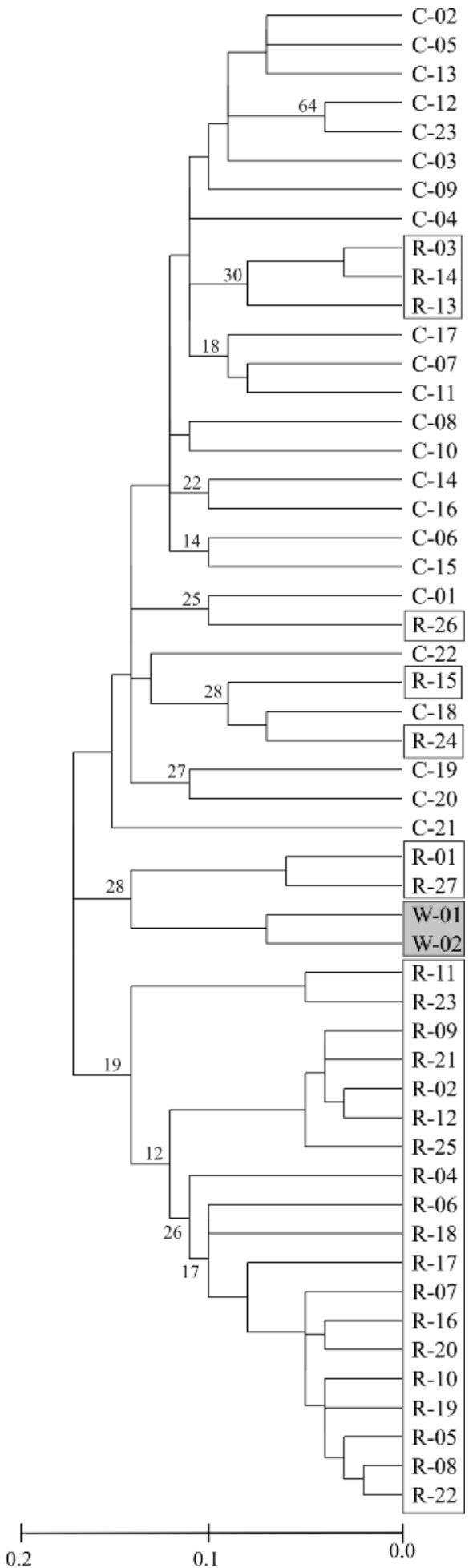

Fig. 3. UPGMA dendrogram based on simple matching coefficient calculated from AFLP data for 52 individuals of Cochlearia polonica from three populations: $\mathrm{C}$ - Centuria, $\mathrm{R}$ - Rajecznica, $\mathrm{W}$ - Wiercica.

analysis the genetic variation of the species could be assessed and described but detailed discussion on genetic processes was hampered to some extent by a too general historical information available.

\section{CONCLUSIONS}

Three populations of Cochlearia polonica constituted the entire present range of this endemic species (one of them gone extinct by 2009). They all developed from transplantations as a conservation effort and none was a natural locality of $C$. polonica. The oldest locality established in the Centuria river springfen developed based on individuals from a threatened natural population and further two were based on the material from the introduced population in Centuria. Over ten individuals that formed the entire preserved genetic pool of the species were used as the original material for the first population. The results could be compared to an extreme bottleneck effect in the total population of the species. Further introductions were based on the material collected from Centuria. The genetic structure of existing populations shows the signature of these transplantation events but the diversity within the main population in Centuria was higher than expected based on a low number of founder individuals.

Only one introduced population, in the springfens in Centuria, adapted to the new locality very quickly, developed dynamically and spread within the available habitat. Site selection for transplantation of this species with specific habitat requirements was very good. The failure of many other attempts at introducing Cochlearia polonica at other sites shows, however, the difficulties of active protection of this species and indicates the need for further studies on the determination of individual habitat requirements and the search for successive new localities, especially in the light of new threats. A planned mine in Zawiercie poses the greatest danger where mechanisms threatening the populations in Centuria are the same as those that caused the complete degradation of natural localities of $C$. polonica in the 1970 s.

\section{ACKNOWLEDGEMENTS}

The authors thank A. Ronikier and W. Paul for critical comments to the manuscript, Jolanta Urbanik for drawing the habit of $C$. polonica and the anonymous reviewer for helpful comments on the paper. The work was financed by a grant from the Polish Ministry of Sciences and Higher Education no. 3 P04G 00724.

\section{LITERATURE CITED}

BAJER A. 1950. Cytological studies on Cochlearia polonica Fröhl. Acta Soc. Bot. Pol. 20: 635-646.

BARYŁA J. 2005. Warzucha polska - Cochlearia polonica E. Fröhlich, uwagi taksonomiczne, siedliska i problemy ochrony. In: Partyka J. (ed.), Zróżnicowanie i przemiany środowiska przyrodniczo-kulturowego Wyżyny Krakowsko-Częstochowskiej. Tom 3 - Suplement., Ojców, 35-40. (in Polish)

CHATER A. O., HEYWOOD V. H. 1964. Cochlearia L. In: Tutin T.G., Heywood V.H., Burges N.A., Valentine D.H., Walters S.M., Webb D.A. (eds.), Flora Europaea. Vol. I. Cambridge, University Press, 313-314.

CHATER A.O., HEYWOOD V.H., WYSE JACKSON P., AKEROYD J.R. 1993. Cochlearia L. In: Tutin T.G., Heywood V.H., Burges N.A., Valentine D.H., Moore D.M. (eds), Flora Europaea. Vol. I. Ed. 2. Cambridge University Press, 378-380.

CIEŚLAK E., RONIKIER M. 2006. Zastosowanie analiz DNA w ustaleniu endemicznego statusu Cochlearia polonica i $C$. tatrae (Brassicaceae). Fragm. Flor. Geobot. Polonica 13: 317-325. (in Polish with English summary)

CIEŚLAK E., KORBECKA G., RONIKIER M. 2007a. Genetic structure of the critically endangered endemic Cochlearia po- 
lonica (Brassicaceae): efficiency of the last-chance transplantation. Bot. J. Linn. Soc. 155: 527-532.

CIEŚLAK E., RONIKIER M., KOCH M.A. 2007b. Western Ukrainian Cochlearia (Brassicaceae) - the identity of an isolated edge population. Taxon 56: 112-118.

ESCUDERO A., IRIONDO J.M., TORRES M.E. 2003. Spatial analysis of the genetic diversity as a tool for plant conservation. Biol. Conserv. 113: 351-365.

FRÖHLICH E. 1936. Cochlearia polonica Fröhlich. In: Szafer W., Pawłowski B. (eds), Rośliny Polskie. Plantae Poloniae Exsiccatae. Ser. II, Cent. III, nr 228. (in Polish)

FRÖHLICH E. 1937. Systematische Studien über polnische Esslöffel (Cochlearia L.) unter Berücksichtigung der verwandten europäischen Arten. Bull. Acad. Pol. Sci. Lettr., Cl. Math.Nat., Ser. B 1: 129-146.

KAŹMIERCZAKOWA R. 2004. Cochlearia polonica E. Fröhlich. Warzucha polska. In: Sudnik-Wójcikowska B., WerblanJakubiec H. (eds), Gatunki roślin. Poradnik ochrony siedlisk i gatunków Natura 2000 - podręcznik metodyczny. T. 9: 100-103. Ministerstwo Środowiska, Warszawa. (in Polish)

KOCH M., HUTHMANN M., HURKA H. 1998. Isosymes, speciation and evolution in the polyploid complex Cochlearia $\mathrm{L}$. (Brassicaceae). Bot. Acta 111: 411-425.

KOCHJAROVÁ J., VALACHOVIČ M., BUREŠ P., MRÁZ P. 2006. The genus Cochlearia L. (Brassicaceae) in the Eastern Carpathians and adjacent area. Bot. J. Linn. Soc. 151: 355-364.

KWIATKOWSKA A. 1957. Rozmieszczenie warzuchy polskiej (Cochlearia polonica E. Fröhlich) w okolicy Olkusza. Fragm. Flor. Geobot. 3: 11-15. (in Polish with German summary)

KWIATKOWSKA A. 1962. Warzucha polska - ginący gatunek endemiczny. Chrońmy Przyr. Ojcz. 18, 3: 5-18. (in Polish)

KWIATKOWSKA A. 1993. Cochlearia polonica Fröhlich - warzucha polska. In: Zarzycki K. and Kaźmierczakowa R. (eds),
Polska czerwona księga roślin. Paprotniki i rośliny kwiatowe. Wyd. 1. Inst. Bot. and Inst. Nat. Conserv. PAS, Kraków, 79-80. (in Polish and English)

KWIATKOWSKA A. 1994. Sprawozdanie z kontroli populacji warzuchy polskiej Cochlearia polonica dokonanych w r. 1994. In: Ocena stanu populacji i zagrożeń rzadkich i zagrożonych gatunków roślin. Raport z badań prowadzonych w roku 1994. Inst. Bot. PAN, Kraków [Manuscript]. (in Polish)

KWIATKOWSKA A. 2001. Cochlearia polonica Fröhlich. Warzucha polska. In: Kaźmierczakowa R., Zarzycki K. (eds), Polska czerwona księga roślin. Paprotniki i rośliny kwiatowe. Wyd. 2. Inst. Bot. and Inst. Nat. Conserv. PAS, Kraków, 166-167. (in Polish)

KULCZYŃSKI S. 1927. Cochlearia L., Warzucha. In: Szafer W. (ed.), Flora Polska. Rośliny Naczyniowe Polski i Ziem Ościennych. T. III. PAU, Kraków, 109-110. (in Polish)

PIECH K. 1924. Doronicum austriacum Jacq. i Cochlearia officinalis L. w okolicy Olkusza. Acta Soc. Bot. Pol. 2: 216-221. (in Polish with German summary)

SOBKO W.G. 1996. Cochlearia polonica E. Froehl. In: ShelyagSosonka Yu.R. (ed.), Chervona Kniga Ukrayini. Roslinniy Svit. Vidavnictvo Ukrayins'ka entsiklopediya imeni M. T. Bazhana, Kiyiv, 95. (in Ukrainian)

SZAFER W., KULCZYŃSKI S., PAWŁOWSKI B. 1924. Rośliny polskie. Książnica-Atlas, Lwów. Pp. XXIII + 736. (in Polish)

SZAFER W., KULCZYŃSKI S., PAWŁOWSKI B. 1953. Rośliny polskie. PWN, Warszawa. Pp. XXVIII + 1020. (in Polish)

SYCHOWA M. 1985. Cochlearia L., Warzucha. In: Jasiewicz A. (red.), Flora Polski. Rośliny Naczyniowe. T. IV. Wyd. 2. PWN, Warszawa, Kraków, 231-234.

ZALEWSKI A. 1886. Zapiski roślinnicze z Królestwa Polskiego i z Karpat. Spraw. Komis. Fizyogr. AU, 20: 171-190. (in Polish) 